\title{
UNDERSTANDING ISLAMIC EDUCATION MANAGEMENT IN DIGITAL ERA: WHAT EXPERTS SAY
}

\author{
Silvia Ekasari'1), Sardjana Orba Manullang'2), Abdul Wahab Syakhrani ${ }^{3)}$, Husna Amin ${ }^{4}$ \\ ${ }^{1}$ STIE Manajemen Bisnis Indonesia \\ email: silvia.ekasari@stiembi.ac.id \\ 2 Universitas Krisnadwipayana, Indonesia \\ email: somanullang@unkris.ac.id \\ ${ }^{3}$ STAI Rasyidiyah Khalidiyah Amuntai, Indonesia \\ email: aws.kandangan@gmail.com \\ ${ }^{4}$ Universitas: UIN Ar-Raniry, Indonesia \\ email: husnaamin63@gmail.com
}

\begin{abstract}
Abstrak
Sejak teknologi mengubah dunia, semua aktivitas bisnis telah berubah total, terutama di negara maju secara signifikan. Alhasil, para pemimpin negara mengadopsi kebijakan yang tidak pernah terjadi yaitu penerapan teknologi di segala bidang sehingga hampir semua aktivitas di dunia menggunakan teknologi untuk melanjutkan aktivitas meskipun belum sepenuhnya siap. Begitu pula dengan memasukkan teknologi ke dalam pendidik.an yang kini semakin digital sehingga industri pendidikan dapat terus berkelanjutan, lebih terjangkau dan mencapai tujuan yang maksimal. Secara k.husus penelitian ini ingin memahami penerapan teknologi dalam tata kelola pendidikan Islam. Untuk alasan ini, upaya pencarian data kami dilakukan dengan bantuan elektronik; Google Scholar, dalam aplikasi lainnya. Analisis kami kemudian melibatkan pengkodean sistem, mengevaluasi, dan menafsirkan data secara mendalam untuk menghasilkan temuan yang valid dan andal. Kami melakukan studi ini dalam desain tinjauan data kualitatif pada publikasi yang diterbitkan dari 2010 bingga 2021 untuk menemukan data terbaru. Berdasarkan pembahasan data temuan, dapat disimpulkean bahwa temuan tersebut telah menjawab beberapa pertanyaan, diantaranya bahwa pibak manajemen lembaga pendidikan Islam mengapresiasi dan mengapresiasi penggunaan teknologi digital atau website dalam program persiapan lulusan yang memiliki kesamaan ilmu dan upskill yang sama. seimbang antara kepentingan dunia dan persiapan akbirat.
\end{abstract}

Kata Kunci: Pengertian Manajemen Pendidikan, Era digital, Perubahan Teknologi, dan tinjauan Publikasi.

\begin{abstract}
Since technology changed the world, all business activities have changed completely, especially in developed countries significantly. As a result, state leaders adopted a policy that had never happened, namely the application of technology in all fields so that almost all activities in the world used technology to continue activities even though they were not fully ready. Likewise, by incorporating technology into education, which is now increasingly digital, the education industry can continue to be sustainable, more affordable, and achieve maximum goals. In particular, this study wants to understand the application of technology in Islamic education governance. For this reason, our data search efforts are carried out with electronic assistance, Google Scholar, in other applications. Our analysis then involves coding the system, evaluating, and interpreting the data in depth to produce valid and reliable findings. We conducted this study in a qualitative data review design on publications published from 2010 to 2021 to find the most recent data. Based on the discussion of the findings data, it can be concluded that these findings have answered several questions, including that the management of Islamic education institutions appreciates and appreciates the use of digital technology or websites in graduate preparation programs that have the same knowledge and upskills balance between the interests of the world and the preparation for the hereafter.
\end{abstract}

Keywords: Definition of Education Management. The digital age, technological change, and publication review reviews 


\section{INTRODUCTION}

In the view of Islamic teachings, everything must be done right. This means knowing governance or management of foreign language terms. (Bashori et al., 2020; Hifza et al., 2020; Hifza \& Aslan, 2020). The term management is a direct translation of the word management which means order, likewise in implementing Islamic education programs. Islam has its name to describe schools, namely madrasas; Madrasah Ibtidaiyah is equivalent to primary education or school, Madrasah Tsanawiyah is equivalent to junior high school, Madrasah Aliyah is equivalent to high school. Likewise, high schools or universities. The word management comes from the root word to diffuse manage, which means organizing, organizing, implementing, organizing, regulating, and treating. (Aslan, 2018; Mukhopadhyay, 2020; Suhardi et al., 2020; Aslan \& Hifza, 2019). The meaning of management is knowing where to go, what difficulties to avoid, what strengths should be exercised, and how piloting the ship and safeguarding and rescuing members and steering the ship is a form of appropriate and directed arrangement within the framework of management so that the objectives to be achieved can be achieved and can be achieved and can be achieved and organized effectively and effectively by the manager or captain-family or education organized by the environment. The term management is also used in family education. According to the term, management coordinates work activities to be completed efficiently. (Buckley \& Irawan, 2015; Hifza, Suhardi, et al., 2020).

Management in this context can explain how to manage Islamic schools, madrasas, and Islamic colleges. Many questions arise what the difference between the management of Islamic education with other educational management is. Management is a process that is a systematic cooperation process that is comprehensive to realize National education. The definition of management is based on Bashori et al., (2020). The meaning of the term management has implications that are interrelated to form a single internal system described in terms of the management process and the use of all resources owned. The use of resources is carried out in collaboration with others effectively, efficiently, and productively to achieve Islamic educational institutions' purpose. The term management represents the object of this management in particular. The core of management in any field is the same; it is just that the variables it faces are different depending on the variables. Regarding the management principles of Islamic education, many Islamic education experts have different opinions, including Fakhruddin, (2011), who said that the principles of 
management of Islamic education in the context of schooling include the management of Islamic education, there are eight principles including sincere, honest, trustworthy, fair, responsible, dynamic, practical, and flexible.

Responsibilities are duties and functions that must be carried out by an educational institution official. (Maujud, 2018). To exercise authority, the authority must be given to him and the implementing system, namely management. If this is violated, authority is reduced, discipline is threatened, the order is compromised, and stability is compromised. Then a solution with a management idea will subside things there. So management is needed to make the best implementation of education from what is available, rather than imposing the will of the education manager on others. (Almasri, 2017). The management concept can be described as: "one head and one plan for the plan for the same group of activities." The idea that the interests of the state should take precedence over citizens' interests and the interests of community groups must also be considered. It is impossible to have the same approach for all management styles and methods. Management ideas are not the same for all managers, but they can be applied to different situations. Revelation texts, both al-Quran and al-hadith, are related to the management of Islamic education. The words (aqwal) of the prophet, scholars, and scholars. (Kuntoro, 2019; Aslan, 2015).

This study is based on the principles of Islamic education management as a theoretical basis. With theological support, it raises the belief that the truth of the message of revelation comes from God. (Harisah, 2018). Simultaneously, the reality of the development of educational and cultural institutions must be in line with Islam and modern educational institutions following the times that are aligned with the realities of academic development. (Hanipudin, 2020; Aslan, 2016). The most important basis of management is planning, planning, organizing, directing, and controlling. The management function is to design, design, organize and control. Truth is based on factual and accurate data, while theoretical rests give birth to truth based on reason and data and have been practiced by many people and times in education management. Theology gives rise to truth-based beliefs on the natural mind and rational mind, and God that is, teachings are a function or task or task of management. It is inseparable from such general management functions. It has its management function. (Fadhillah, 2016).

The term management of Islamic education was popularized in the 19th century by the local mayor and is still used in some circles today. (Nata, 2012). 
It has been used since the 1980s about an Islamic model of educational management based on the Koran and ulama's thinking. This means "education" in Indonesian which is often translated as "education management" in English and "education planning" in the local language, or "education management" in Spanish. Organizing is the management's primary activity to organize all resources, including the human element, to be done neatly. Implementation in Islamic education is a process of determination, structure, activity, interaction, coordination, authority, structural design, and coordination. (Lindenberg \& Foss, 2011).

An institution in Islam that manages education can run smoothly and according to its goals if it aligns with the principles designed. (Hartung, 2014). Organizational design, freedom, justice, and deliberation. Islamic teachings always encourage adherents to do everything in an orderly manner because untidy truths will be easily destroyed. Organizing occurs because the work required is too much for one person to handle. The briefing is the process of guiding co-workers. The debriefing content is conveyed in the form of orders, prohibitions, or instructions. (KouchakiPenchah et al., 2016). The brief recipient's ability to get the Briefing content so that the recipient can appropriately execute it in the end. The contents of a brief can be anything that can be in the form of orders, prohibitions, or instructions. It can be concluded that the provisioning function is to provide direction to employees so that they can work effectively towards the predetermined targets. In Islamic education, management is a process based on colleagues' religious principles so that those concerned want to carry out their duties seriously and passionately with the highest sincerity. (Kurniawati, 2018). This is a. a way to ensure that the activity follows the plan that has been determined operationally. Implementation of operational activities to ensure that activities are carried out in an orderly manner to ensure that the plan follows the plan was accurate.

The improvement of the mechanical time 4.0 is a test for the current world, besides Islamic guidance. Instructors genuinely need to set themselves up for logically complex challenges. This informational limit can be cultivated through transmission, both easygoing and nonformal (tutoring) structures. The complexity of the challenges is called Kompleksoh. Guidance is defied with mechanical advances. (Putra et al., 2020; Putra \& Aslan, 2020). As per Fonna, (2019) the advancement of the Industrial upset 4.0 in different fields has changed the way people live, particularly work and study. This is character development for the advancement of progressively refined data and innovation. 
Notwithstanding, as the Islamic schooling supervisor, it is advantageous for every one of these developments and modern insurgencies.

The Japanese government embraced the Society 5.0 idea to expect worldwide patterns because of its rise. The creator asks: How are the difficulties of Islamic training in confronting society 5 . The creator gives issue definitions to assist understudies with understanding the difficulties the Islamic training framework faces in confronting society's rise and improvement later on. The creator presumes that society 5.0 is the response to the difficulties that emerge because of the period of the modern insurgency 4.0 and the eventual fate of training will be molded by innovation, yet as an age of Muslims focusing on mechanical arrangements with Islamic characters that are keen and insightful. (Dimas et al., 2019).

The development of Islamic education in the country has experienced ups and downs since the colonial era at the end of the 16th century. (Raya, 2018). During the New Order era, Islamic education seemed to be increasingly developing with a transformation in strengthening the constitution for Islamic education. Postreform Islamic education must face several challenges and problems, including (1) globalization, which hit every country sector, including education, which gave birth to a new paradigm. Azis, (2019) in his study of
Islamic Education, defines Islamic education as a process of behavior change that occurs in individuals and society. So Islamic education can be designed to develop all human potential by adhering to the Koran and Hadith principles. (Fitri, 2018). The emphasis is on searching for knowledge, mastery, and development based on worship to Allah SWT. It is the practice of knowledge or the basis of responsibility to Allah SWT.

The Industrial Revolution 4.0, also called the cyber era or the era without space and time, gave birth to scientifictechnological advances that gave birth to intelligent machines, autonomous robots, and even Artificial Intelligence (AI). All fields and at the same time create complex and difficult challenges. In this era, human resources are dubbed the "millennial generation" who were born after 1980. They live and grow every day in the digital world, very familiar with modern technology. The millennial generation population is over 77 million, one and a half times larger than Generation X and its size. This is a real challenge for Islamic education governance in the country in an era of technology where everything is high technology. (Putra et al., 2020).

The problem of Islamic education in the Industrial Age 4.0 is between the insistence from the first on mental gradation and civilization to manage education with an 
educational background as a legacy of the nation's ancestors. It is clear that Islamic education experiences many complex and intricate problems. (Hidayat, 2015); (Manullang, 2020; Manullang, 2021). These problems include a dichotomy (dichotomous), the knowledge that is still general (too general knowledge), and a lack of enthusiasm for inquiry. People still think that Islamic religious education is education that is only related to life after death. The community prefers public schools that are more promising for their future than religion-based schools. (Imelda, 2017; Aslan \& Hifza, 2020; Aslan \& Setiawan, 2019). Islamic boarding schools, madrassas, and universities were empty of visitors. In a country where the majority of the population is Muslim, educational institutions are not in demand. Another problem that remains an obstacle in Islamic education institutions is the lack of research. The enthusiasm for research from practitioners of Islamic education is still very low. (Syam, 2019).

As indicated by Yuhana \& Aminy, (2019) Islamic schooling in Indonesia deals with different issues and holes in different viewpoints. Instruction in Indonesia additionally utilizes Western writing that is more sterile and does not rely upon developing confidence and Islam esteems. Wellsprings of data should be offset with analytical writing composing, which is mainly founded on Islamic qualities. Islamic schooling has a significant errand of building up the nature of (HR) with the goal that Indonesian individuals can have a superior nature of instruction and a superior life. (Walidin, 2016). Islamic education still uses the old system (classical), which relies on the rote system. Lack of student involvement in the teaching and learning process causes the teaching and learning process to be monotonous and boring Priyatna, (2017) notes that teacher innovation and creativity in teaching are very lacking and almost invisible. Language is the primary medium in the Teaching process and must be conveyed in a way that is easy to understand and straightforward. If students' understanding of the material goes well, the learning outcomes will be excellent. If language delivery experiences problems and does not work well, learning outcomes will be hampered. (Sinambela, 2021).

Indeed, if Islamic education is not managed with modern management, Islamic education institutions and institutions are identical to backwardness in information, communication, and technology because of their limited budget. (Azra, 2017). Moreover, with minimal funding sources, it hinders the development of potential madrasahs. Technology is the most urgent need to develop all educational institutions, general education, or religion in this modern era. Islamiyah, (2021) notes that Islamic 
education has to respond to the challenges of globalization and modernization. In other words, Islamic educational institutions tend to be less organized in their management. The label of Islamic education is only related to life after death, which is still attached to the broader community's minds. (Priatmoko, 2018).

Amin, (2016) suggests that the practice of Islamic education so far should not only stick to the old legacy.On real challenges, it does not do much artistic, imaginative, or critical thought. The educational paradigm stresses an intellectualism-verbalizes approach, ignoring the relevance of educational experiences and humanistic contact between teachers and students. (Rozi, 2019). There have been no significant reform efforts undertaken by Islamic education to keep pace with general education's rapid development. Reform referred to here is renewal in all matters relating to methods, systems, management, goals, vision, mission, and future orientation of Islamic Education. Minimal efforts at reform, as mentioned above, are a reality that can be found and witnessed in most Islamic education. (Qodir, 2013).

Likewise, Afifudin, (2020) argues that the realm of humanity, which should be the main target of Islamic development, has become marginalized and not adequately cared for. The public's expectation that Islamic education is an educational solution in the current moral decadence era has not yet been realized. Some of the problems that remain the "stumbling block" of Islamic education are the still dichotomy. The still weak research culture in Islamic educational institutions. Educational evaluation system which has been based on national exam scores. This problem seems to be a big challenge for Islamic education. In this era of disruption, all sub-systems of the country must integrate digitalization with the manufacturing paradigm. All Islamic education results must be in line with market and industrial needs in the Industrial Revolution Era 4.0. (Mintasih, 2018).

After understanding the background of the problem of Islamic education in this digital era, we can explain again that the purpose of Islamic religious education is to mature students by guiding current knowledge and skills but still in the corridor of the Islamic religion that directs and educates students to understand and study the teachings of Islam as a provision for life in the world and the hereafter Ahmad \& Mirza, (1966).

The benefit of analyzing the opinions of experts from dozens of publications on Islamic education management is that we want to understand consistently and simultaneously the changes and progress of the evidence from the studies of experts so that later we will improve our abilities as educational leadership both in schools as teachers, researchers, and the community in 
making and supporting policies and leading the planning of the development of religious knowledge that is aligned with current science and technology as well as how the two variables of Islamic education and technological sophistication can accommodate the needs of the Muslim community of the millennial generation, entering education and the world of work. (Honicke \& Broadbent, 2016).

\section{METHOD}

Since technology changed the world, all business activities have completely changed, especially in most countries. As a result, all state leaders adopted a policy that never happened, namely the application of technology in all fields so that almost all companies in the world used technology to continue their business even though they were not as unprepared. The reason is how to involve technology, especially digital education; their education business can still survive, be more accessible and reach its goals. In particular, this study wants to understand the application of technology in Islamic education governance. We searched the data for this study with the Google scholar engine and other data search engines. In short, the process begins with understanding the problems of study, analyzing data, passing through the coding system, evaluating and critical interpretation of the data that has become a trend in the governance of religious education and exchange technology-experts through visiting their publications both national and international. We rely on secondary data and descriptive qualitative designs under the direction and adoption of the study findings in the bio-qualitative studies and review data on modern-century education and teaching technology. (Marshall et al., 2013).

\section{RESULT AND DISCUSSION}

This section will present the results of a review of many publications as evidence of findings on how to understand management and how to practice Islamic education in the area of technology through a systematic literature review. Meanwhile, the discussion to find the importance of the findings and evidence of previous studies and the relevance of our findings with the same data and research that has been carried out in the previous context and situation will be presented in the next section.

The first understanding of what the experts say comes from Mansir \& Karim, (2020) who examined the Islamic training learning approach in shaping students' enthusiastic knowledge in the computerized era. They see the Islamic teaching has a significant role in shaping morals and ethics in individuals and the state. This is the ideal opportunity for Islamic schools to find out how to build instructional techniques that work through a tremendously important setting. This result is a logical commitment 
and ideas about fundamental ways of dealing with Islamic training and building students' enthusiastic knowledge information gathering system by breaking down writing using broad-based elaboration techniques.

Next, Huda et al., (2020) examined how to manage a learning framework using Auguste Comte's three laws: An Islamic school example. Since June 2006, Pondok Pesantren Tebuireng has provided Islamic guidance. Understanding coming from different schools lacked Islamic training and faced problems while taking courses. The examination findings revealed that all levels of education in Islamic schools (Pesantren) should provide science-based subjects. There should be harmony between Islamic and science-based training. Such is the finding of the research carried out, which is very reasonable that the administration of the learning framework is needed in Tebuirng Islamic Middle School.

The following study is Syaifullah \& Surawardi, (2020) regarding the implementation of WASAKA, a concept in Islamic education for the people of Banjar, South Kalimantan, Era 4.0. Waja to Kaputing were spoken by Pangeran Antasari, a public legend from South Kalimantan. These people with respect that is firm, courageous, reasonable, wise, and careful. These characteristics are appropriate and can be synergized with Islamic study guidance in the Banjar community in the era of revolution 4.0. Overall, the execution of WASAKA thoughts can answer the decrease in facial character in 4.0 time. This study emphasizes the integration of Islamic character with the digital era's management in the Muslim generation, who are also millennial citizens.

Understanding the management strategy of the study by Satispi \& Taufiqurokhman, (2018) emphasizes that an Islamic education policy is needed in Indonesia's digital era. This paper presents the Islamic schooling strategy techniques in the later stages. Islamic training as a subsystem of general education needs to manage and implement progress and be maintained. Computer learning time is the total time during school students must be trained to become proficient. So their studies on planning the value and potential of Human Resources must be prepared in full. The learning methodology depends on the need for the educational program to change to a computerized library.

Meanwhile, Asad et al., (2018) through a critical review of Islamic and conventional banking in the digital era by Pakistan's case, was done. Islamic banking is creating a high velocity in economies considered the undertaking's managers and countered interest-based cash-related structure. This assessment's inspiration is to understand the rule contrasts in Islamic and conventional banking in Pakistan dependent on cost and 
benefit examination. Islamic banks' productivity and achievement are better than that of non-Islamic banks, even in current electronic economies. The examination surveys the upstanding addendum of Islamic banking and differentiation it from standard banking. The trained professionals and methodology makers need to search for heading for strengthening of the structure.

Putra et al., (2020) studied the relevance of education release revolution 4.0 in the perspective of primary Islamic education in Indonesia (Paulo Freire's Thought Analysis Study). This article examines Paulo Friere's thinking, the coincidence guide's meaning, and its significance in the inventive 4.0 clock. Opportunities in Islam alluded to are free but not as accessible as paying little attention to the suitable characteristics. The teaching opportunities permitted in Islam are opportunities to prepare those limited by Islam's characteristics for the qualities that can shape the character of the believing human. This article relies on the related writing.

Likewise, Karim \& Fauziyah, (2018) study, which raised the difficulties of Islamic training in modern times 4.0, was relevant. There have been changes and movements in the two sources and learning strategies of Islamic Education. This paper discusses the problems and difficulties of PAI in modern times 4.0. This is done in an interpretive worldview with a subjective methodology through archival study and substance investigation. There is a significant change in the notion of quality and lessons, which will become the focal point of the pesantren.

Meanwhile, Abidin, (2020) regarding the understanding of learning management science in Islamic boarding schools in the Digital Era 4.0. was also essential. The electronic-learning ability of students in Gontor 12 Tanjung Jabung Timur today, the school of Islamic life experiences, is the main thing that must be remembered for pesantren education as an executive framework. The aim is to increase the ability of students to be serious about governmentfunded graduate schools.

Closing the search for evidence of the importance of the study of Jailani \& Miskam, (2020) proves that the affirmation of Islamic schools in the era of the fourth industrial revolution is very relevant to Islamic education's objectives based on the Quran. This paper reveals an understanding of the moving realities expected in the fourth (fourth IR) Industrial Revolution. The subject of happiness, the revival of the custom of Islamic intellectualism, and the human being's mission are the rules' attention. These disclosures are discussed in 4 critical rooms in the pesantren section, which are a repetition of the Islamic drafting hypothesis, arranged in an instructive structure with learning techniques that are based on character, fundamental 
investigative practices as well as clean academic ability and authority to work on an emphasis on head standards.

Finally, the findings of Ismail et al., (2020) on the study of the competence of millennial Islamic education teachers in facing the challenges of the industrial revolution were done. This exploration's motivation is to see how the skills of Islamic millennial coaching instructors are in the face of difficulties during the mechanical unrest 4.0. The results of scientists' exploration through several references reveal that capabilities are character, execution, and education. Suggestions for additional scientists are needed to concentrate more on new college graduates' competence in facing difficulties.

\section{DISCUSSION}

The study's main objective is to find an understanding of the management of Islamic education in the digital era through the search for evidence of evidence from the findings of previous studies. Besides this review, we run it to get a purpose, namely to identify trends in the integration of technology into the teaching system in Islamic schools and institutions. This is an opportunity to get an in-depth understanding of the governance domain of the Islamic education sector. So that later our findings will be a set forth for a proposal on the making of a governance policy for Islamic education in the country and turn this finding into a study product to support the success of Islamic education as well as a strategy to address the opportunities in the realm of Islamic education.

Based on the findings of many publications that we have reviewed, they implicitly confirm that we have answered the questions and hypotheses of our study where the majority of publications say Islamic education is in line with the trend of education in the era of technology in Islamic religious schools such as madrasas and Islamic universities. What makes our findings in line with most publications is the effort to integrate religious values into the teaching of technology in religious schools. This finding clearly shows the findings of field evidence that the teaching of technology in Islamic madrassas is a superior action and program that combines education through Islam with the Quran, and the trend of advancing times in technology has become a modern-day solution. Our findings are in line with Untung, (2019) findings, which stated the totality of managing the quality of Islamic education in a globalization era. Other findings include Priyanto, (2020) incorporating character education to efforts to strengthen Islamic Education in the Industrial Era 4.0.

Students in Islamic madrasas are social and civilized creatures. The management of 
Islamic education is a system that allows students to enable them to lead a life according to Islamic ideology by continuing to appreciate external civilizations while preserving the values they have obtained was essential. Many findings show madrasa students that it will be challenging to adapt to this technological change, which is an assumption that has been refuted by evidence from previous studies. In this case, Islam is a religion that respects change but still affirms Muslim identity and ancestral wisdom as a group that believes in God. Findings that are relevant to our findings e.g., Ratnaningsih et al., (2020) studied Islamic education's role in increasing democratic attitudes and religious tolerance in high school students in Indonesia. Another finding of the Mass is Kastolani, (2019) with the theme of digitization among Islamic universities in Indonesia.

\section{CONCLUSION}

This study's questions and objectives have been answered by reviewing the published evidence from experts on the indepth understanding of Islamic education and governance in the digital era where all human activities have been computerized. Our findings confirm that understanding Islamic education's governance has become the primary goal of Islamic religious school managers from madrasas to Islamic tertiary institutions. Is a solution where the technology teaching agreement among madrasas is a modern solution? The assumption that the religious school does not respect technology and the changing times is a teacher. Many findings have spontaneously challenged if there are still doubts about the commitment to managing Islamic education in this country amid an increasingly global era with technological solutions in all sectors

\section{REFERENCES}

Abidin, Z. (2020). Educational Management of Pesantren in Digital Era 4.0. Jurnal Pendidikan Agama Islam, 17(2), 203-216.

Afifudin, R. (2020). Manifestasi Teologi Tanah Hassan Hanafi Dalam Gerakan Reclaiming Petani Di Rotorejo-Kruwuk Blitar. Kontemplasi: Jurnal Ilmu-Imu Ushuluddin, 8(1), 143-176.

Ahmad, G., \& Mirza, H. (1966). The teachings of Islam. al-Tabshir.

Almasri, M. N. (2017). Manajemen Sumber Daya Manusia: Imlementasi Dalam Pendidikan Islam. Kutubkhanah, 19(2), 133-151.

Amin, M. (2016). IMPLEMENTASI PENDIDIKAN KRITIS DALAM PENDIDIKAN ISLAM DI SEKOLAH TINGGI AGAMA ISLAM (STAI) AL-AMIN DOMPU. NUANSA, 5(1), 61-80. 
Asad, M., Ahmad, I., Haider, S. H., \& Salman, R. (2018). A Crital Review of Islamic and Conventional Banking in Digital Era: A Case of Pakistan. International Journal of Engineering \& Technology, 7(4), 57-59.

Aslan. (2015). PENGEMBANGAN KURIKULUM KE ARAH PENINGKATAN MUTU PENDIDIKAN ISLAM DALAM MENGHADAPI MASYARAKAT EKONOMI ASEAN (MEA).

Aslan. (2018). Dinamika Pendidikan Islam di Zaman Penjajahan Belanda. SYAMIL: Jurnal Pendidikan Agama Islam (Journal of Islamic Education), 6(1), 39-50. https://doi.org/10.21093/sy.v6i1.10 24

Aslan, A. (2016). Kurikulum Pendidikan Vs Kurikulum Sinetron. Khazanab: Jurnal Studi Islam Dan Humaniora, 14(2), 135-148.

Aslan, A., \& Setiawan, A. (2019). InternalIzatIon of Value educatIon In temajuk-melano malaysIa Boundary school. Edukasia: Jurnal Penelitian Pendidikan Islam, 14(2).

Aslan \& Hifza. (2019). Kurikulum Pendidikan Masa Penjajahan Jepang Di Sambas. Edukasia Islamika, 4(2), 171-188.

https://doi.org/10.28918/jei.v4i2.22 95
Aslan \& Hifza. (2020). The Community Of Temajuk Border Education Values Paradigm On The School. International Journal of Humanities, Religion and Social Science, 4(1), 13-20.

Azis, R. (2019). Ilmu Pendidikan Islam.

Azra, A. (2017). Surau: Pendidikan Islam Tradisi dalam Transisi dan Modernisasi. Kencana.

Bashori, B., Prasetyo, M. A. M., \& Susanto, E. (2020). Change Management Transfromation In Islamic Education Of Indonesia. Social Work and Education, 7(1), 72-85.

Buckley, P., \& Irawan, I. (2015). The Scientific Paradigm of Islamic Education Management: Phenomenology Perspective. Jurnal Pendidikan Islam UIN Sunan Gunung Djati, 2(1), 1-29.

Dimas, P., Montani, L., Pereira, J. A., Moreno, D., Trötzmüller, M., Gerber, J., Semenkovich, C. F., Köfeler, H. C., \& Suter, U. (2019). CNS myelination and remyelination depend on fatty acid synthesis by oligodendrocytes. Elife, 8, e44702.

Fadhillah, K. (2016). Manajemen Mutu Pendidikan Islam di Pesantren (Studi di Pondok Modern Darussalam Gontor). At-Ta'dib, 10(1).

Fakhruddin, A. (2011). Prinsip-Prinsip Manajemen Pendidikan Islam dalam Konteks Persekolahan. Jurnal 
Pendidikan Agama Islam-Ta'lim, 9(2), 199-212.

Fitri, A. (2018). Pendidikan karakter prespektif al-Quran hadits. TA'LIM: Jurnal Studi Pendidikan Islam, 1(2), 258-287.

Fonna, N. (2019). Pengembangan Revolusi Industri 4.0 dalam Berbagai Bidang. Guepedia.

Hanipudin, S. (2020). Konsepsi Guru Modern Dalam Pendidikan Islam. Al-Munqidæ: Jurnal Kajian Keislaman, 8(3), 338-357.

Harisah, A. (2018). Filsafat Pendidikan Islam Prinsip dan Dasar Pengembangan. Deepublish.

Hartung, J.-P. (2014). A System of Life: Mawdìdi and the Ideologisation of Islam. Hurst \& Company Limited.

Hidayat, N. (2015). Peran dan Tantangan Pendidikan Agama Islam di Era Global. Jurnal Pendidikan Agama Islam, 12(1), 61-74.

Hifza \& Aslan. (2020). The Model of Competitive Advantage Development in Private Islamic Education Institutions dalam "BASA 2019: Proceedings of the Third International Seminar on Recent Language, Literature, and Local Culture Studies, BASA, 20-21 September 2019, Surakarta, Central Java, Indonesia. European Alliance for Innovation.

Hifza, Juliana, Palapa, A., Maskur, \& Aslan. (2020). The Strategic Foundation for
Competitive Excellent Development in Integrated Islamic Primary Schools in Indonesia. International Journal of Advanced Science and Technology, 29(12s), 1747-1753.

Hifza, Suhardi, M., Aslan, \& Ekasari, S. (2020).

KEPEMIMPINAN PENDIDIKAN ISLAM DALAM PERSPEKTIF

INTERDISIPLINER. Nidhomul

Haq: Jurnal Manajemen Pendidikan Islam, 5(1), 46-61. https://doi.org/10.31538/ndh.v5i1. 518

Honicke, T., \& Broadbent, J. (2016). The influence of academic self-efficacy on academic performance: A systematic review. Educational Research Review, 17, 63-84.

Huda, S., Tsani, I., Syazali, M., Umam, R., \& Jermsittiparsert, K. (2020). Retracted: The management of educational system using three law Auguste Comte: A case of Islamic schools. Management Science Letters, 10(3), 617-624.

Imelda, A. (2017). Implementasi Pendidikan Nilai Dalam Pendidikan Agama Islam. Al-Tadrkiyyah: Jurnal Pendidikan Islam, 8(2), 227-247.

Islamiyah, U. H. (2021). Islamic Education Responds to The Challenges of Globalization. Islam Universalia, 2(3). 
Ismail, S., Ruswandi, U., \& Erihadiana, E. (2020). The Competence of Millennial Islamic Education Teachers in Facing The Challenges of Industrial Revolution. Nazhruna: Jurnal Pendidikan Islam, 3(3), 389-405. Jailani, M. R. M., \& Miskam, N. A. A. (2020). The roles of Islamic university in the Fourth Industrial Revolution Era (4th IR). 'Abqari Journal, 23(2), 57-76.

Karim, M., \& Fauziyah, N. (2018). The challenges of Islamic education in the industrial era 4.0. Proceeding International Conference on Islamic Education (ICIED), 3(1), 28-32.

Kastolani, K. (2019). DIGITAL REORIENTATION OF ISLAMIC HIGHER EDUCATION IN INDONESIA. AKADEMIKA: Jurnal Pemikiran Islam, 24(1), 151164.

Kouchaki-Penchah, H., Sharifi, M., Mousazadeh, H., ZareaHosseinabadi, H., \& NabaviPelesaraei, A. (2016). Gate to gate life cycle assessment of flat pressed particleboard production in Islamic Republic of Iran. Journal of Cleaner Production, 112, 343-350.

Kuntoro, A. T. (2019). Manajemen Mutu Pendidikan Islam. Jurnal Kependidikan, 7(1), 84-97.
Kurniawati, D. (2018). Manajemen Sumberdaya Manusia Dalam Perspektif Islam Dan Elevansinya Dengan Manajemen Modern. Ijtimaiyya: Jurnal Pengembangan Masyarakat Islam, 11(1), 19-40.

Lindenberg, S., \& Foss, N. J. (2011). Managing joint production motivation: The role of goal framing and governance mechanisms. Academy of Management Review, 36(3), 500-525.

Mansir, F., \& Karim, A. (2020). Islamic education learning approaches in shaping students' emotional intelligence in the digital age. Hayula: Indonesian Journal of Multidisciplinary Islamic Studies, 4(1), 67-86.

Manullang, S. O. (2020). Understanding of Modern Society Perception on Sociology of Islamic Law in Indonesia. International Journal of Humanities, Literature and Arts, 3(1), 85-92.

Manullang, S. O. (2021). PERUBAHAN SOSIAL MASYARAKAT PEDESAAN DI ERA TEKNOLOGI. Cross-Border: Jurnal Kajian Perbatasan Antarnegara, Diplomasi Dan Hubungan Internasional, 4(1), 83-88.

Marshall, B., Cardon, P., Poddar, A., \& Fontenot, R. (2013). Does sample size matter in qualitative research?: A 
review of qualitative interviews in IS research. Journal of Computer Information Systems, 54(1), 11-22.

Maujud, F. (2018). Implementasi FungsiFungsi Manajemen dalam Lembaga Pendidikan Islam (Studi Kasus Pengelolaan Madrasah Ibtidaiyah Islahul Muta'allim Pagutan). Jurnal Penelitian Keislaman, 14(1), 31-51.

Mintasih, D. (2018). Mengembangkan literasi informasi melalui belajar berbasis kehidupan terintegrasi PBL untuk menyiapkan calon pendidik dalam menghadapi era revolusi industri 4.0. ELEMENTARY: Islamic Teacher Journal, 6(2), 271-290.

Mukhopadhyay, M. (2020). Total quality management in education. SAGE Publications Pvt. Limited.

Nata, H. A. (2012). Manajemen Pendidikan: Mengatasi Kelemahan Pendidikan Islam di Indonesia. Kencana.

Priatmoko, S. (2018). Memperkuat Eksistensi pendidikan Islam di era 4.0. TA'LIM: Jurnal Studi Pendidikan Islam, 1(2), 221-239.

Priyanto, A. (2020). The Refinement on Character education to Strengthening Islamic Education in Industrial Era 4.0.

Priyatna, M. (2017). Manajemen pengembangan sdm pada lembaga pendidikan Islam. Edukasi Islami: Jurnal Pendidikan Islam, 5(09), 21.
Putra, P. \& Aslan. (2020). PENGEMBANGAN BAHAN AJAR BERBASIS IMTAQ DAN IPTEK DI ERA REVOLUSI INDUSTRI 4.0 PADA MATA PELAJARAN SAINS MADRASAH IBTIDAIYAH. Ta'Limuna: Jumal Pendidikan Islam, 9(1), 1-15. https://doi.org/10.32478/talimuna. v9i1.345

Putra, P., Mizani, H., Basir, A., Muflihin, A., \& Aslan, A. (2020). The Relevancy on Education Release Revolution 4.0 in Islamic Basic Education Perspective in Indonesia (An Analysis Study of Paulo Freire's Thought). Test Engineering \& Management, 83, 10256-10263.

Qodir, Z. (2013). Deradikalisasi Islam dalam perspektif pendidikan agama. Jurnal Pendidikan Islam, 2(1), 85-107.

Ratnaningsih, S., Nahartini, D., Permana, Y. W., \& Syafruddin, D. (2020). The role of islamic education on increasing democratic attitude and religious tolerance in high school students in Indonesia. 2nd International Conference on Islam, Science and Technology (ICONIST 2019), 125128.

Raya, M. K. F. (2018). Sejarah Orientasi Pendidikan Islam di Indonesia (Dari Masa Kolonial Hingga Orde Baru). Jurnal Pendidikan Islam, 8(2), 228-242. 
Rozi, B. (2019). Problematika Pendidikan Islam di Era Revolusi Industri 4.0. Jurnal Pendidikan Islam, 9(1), 33-47.

Rusdiana, A. (2014). Konsep Inovasi Pendidikan (1st ed.). PUSTAKA SETIA.

Satispi, E., \& Taufiqurokhman, T. (2018). Islamic Education Policy Strategy in Indonesia's Digital Era. PROCEEDINGS

INTERNATIONAL CONFERENCE BKSPTIS 2018, $O(0), \quad$ Article $0 . \quad$ http://lppmunissula.com/jurnal.unissula.ac.id/in dex.php/bksptis/article/view/3609

Sinambela, L. P. (2021). Manajemen Sumber Daya Manusia: Membangun tim kerja yang solid untuk meningkatkan kinerja. Bumi Aksara.

Sirojuddin, A. (2018). Partisipasi Masyarakat Tariqah Pada Penyelenggaraan Pendidikan Di Yayasan Lpmnu Talang Prigen Pasuruan. Nidhomul Haq: Jurnal Manajemen Pendidikan Islam, $\quad 3(2), \quad$ 148-161. https://doi.org/10.31538/ndh.v3i2. 213

Suhardi, M., Mulyono, S., Syakhrani, H., Aslan, A., \& Putra, P. (2020). Perubahan kurikulum lembaga pendidikan Islam di Sambas pada masa Kesultanan Sambas. Ta'dibuna: Jurnal Pendidikan Islam, 9(1).

Syaifullah, A., \& Surawardi, S. (2020). WASAKA Concept Implementation in Islamic Education towards Banjar Society of South Kalimantan in 4.0 Era. Khalifa: Journal of Islamic Education, 4(1), 32-48.

Syam, A. R. (2019). Guru dan Pengembangan Kurikulum Pendidikan Agama Islam di Era Revolusi Industri 4.0. TADRIS: Jurnal Pendidikan Islam, 14(1), 1-18.

Untung, S. (2019). Total Quality Management in Islamic Education in Globalization Era. HIKMATUNA, 5(2), 169-181.

Walidin, W. (2016). Arah pengembangan sumberdaya manusia dalam dimensi pendidikan islam. Jurnal Edukasi: Jurnal Bimbingan Konseling, 2(2), 147163.

Yuhana, A. N., \& Aminy, F. A. (2019). Optimalisasi peran guru pendidikan agama Islam sebagai konselor dalam mengatasi masalah belajar siswa. Jurnal Penelitian Pendidikan Islam,[SL], 7(1), 79-96. 